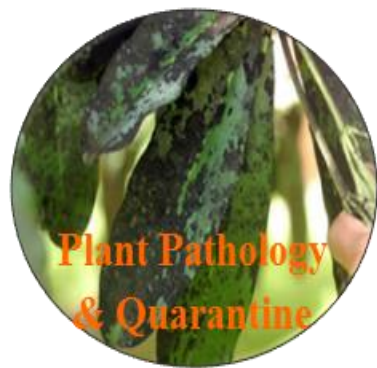

\title{
Record of a new host of the wood-rotting fungus Hexagonia tenuis
}

\section{De $A B *$}

\author{
*Guest lecturer \\ Department of Microbiology, The University of Burdwan, Burdwan-713104, West Bengal, India
}

De AB 2018 - Record of a new host of the wood-rotting fungus Hexagonia tenuis. Plant Pathology \& Quarantine 8(1), 58-62, Doi 10.5943/ppq/8/1/8

\begin{abstract}
Basidiocarps of Hexagonia tenuis were found on a living plant of Nerium odorum in Burdwan, West Bengal, India. Nerium odorum (family Apocynaceae) is reported as a new host of $H$. tenuis. It is evident that basidiocarp development of $H$. tenuis is not affected by diameter of the wood of host plants.
\end{abstract}

Key words - Hexagonia tenuis - host - India - Nerium odorum - West Bengal

\section{Introduction}

During a survey of wood-rotting fungi, conducted in West Bengal, India during 2012-2017, basidiocarps of a species of Hexagonia Fr., causing white rot, were observed on wood of a living plant of Nerium odorum Sol. (= Nerium indicum Mill.) of family Apocynaceae. May (2017) suggested that minor variations in morphology between collections from different locations are sufficient to erect new species. So, these basidiocarps were studied morphologically to confirm the identification of the species.

\section{Materials \& Methods}

Each basidiocarp was collected and placed in separate polythene bags. Thin sections from various parts of each basidiocarp were cut using sharp blades and put in 5\% $\mathrm{KOH}$ solution. The sections were stained with cotton blue, teased apart with sharp needles and mounted in lactophenol. Microscopic observations were made using both $40 \times$ and $100 \times$ magnifications. A piece of each basidiocarp was attached onto the underside of a Petri dish lid and then the lid was inverted over the dish. The pores were situated over malt agar medium and after one or two hours spores were discharged onto the medium and germinated to form cultures. Oxidase tests were carried out with the cultures on media containing 1.5\% Difco malt extract agar and $0.5 \%$ gallic acid and tannic acid, respectively, as described by Davidson et al. (1938). Basidiocarps were deposited in the Department of Microbiology, The University of Burdwan, West Bengal, India.

\section{Results}

The morphological and anatomical features of the fungus observed indicate that it is Hexagonia tenuis (Hook.) Fr. (Fig.1). 


\section{Morphological characters of basidiocarps}

Basidiocarps solitary, sessile, dimidiate with narrow base, applanate to flabelliform, slightly concave, $4.0-12.0 \times 3.0-8.0 \times 0.2-0.3 \mathrm{~cm}$, corky-coriaceous; upper surface (Fig. 3) pale brown to dark brown, some with greyish black colour at the centre, uneven, concentrically striate to zonate; margin entire and thin; hymenial surface (Fig. 2) greyish, pores hexagonal, 10-12 per $\mathrm{cm}$.

\section{Microscopic characters of basidiocarps}

Hyphal system trimitic. Generative hyphae (Fig. 6a) hyaline, thin-walled, branched, clamped, 1.5-3.0 $\mu \mathrm{m}$ wide. Skeletal hyphae (Fig. 6b) subhyaline to yellowish brown, straight or flexuous, thick-walled to solid, occasionally with septa towards the apex, 3.0-6.0 $\mu \mathrm{m}$ wide. Binding hyphae hyaline to subhyaline, thick-walled to solid, much branched, branches mostly short and coralloid (Fig. 6c), a few freely branched but short (Fig. 6d) and flexuous, 1.5-3.2 $\mu \mathrm{m}$ wide, reddish brown, thin-walled to slightly thick-walled cuticular cells (Fig. 6e) with irregular projections in the crustose area at the base of the pileus surface. Basidia (Fig. 6f) narrow clavate, 4-sterigmate, 15.0-22.0 $\times$ 8.0-10.0 $\mu \mathrm{m}$. Subhyaline to pale brown cystidioid hyphae formed at apical ends of skeletal hyphae, present more commonly in sterile pore mouths. Basidiospores (Fig. 6g) hyaline, thin-walled, cylindrical, $10.0-15.0 \times 4.0-6.0 \mu \mathrm{m}$.

Oxidase reactions - Positive on both gallic acid agar (GAA) (Fig. 4) and tannic acid agar (TAA) (Fig. 5), which is indicated by black zone around the colonies.

Host - Nerium odorum Sol. (=Nerium indicum Mill.)

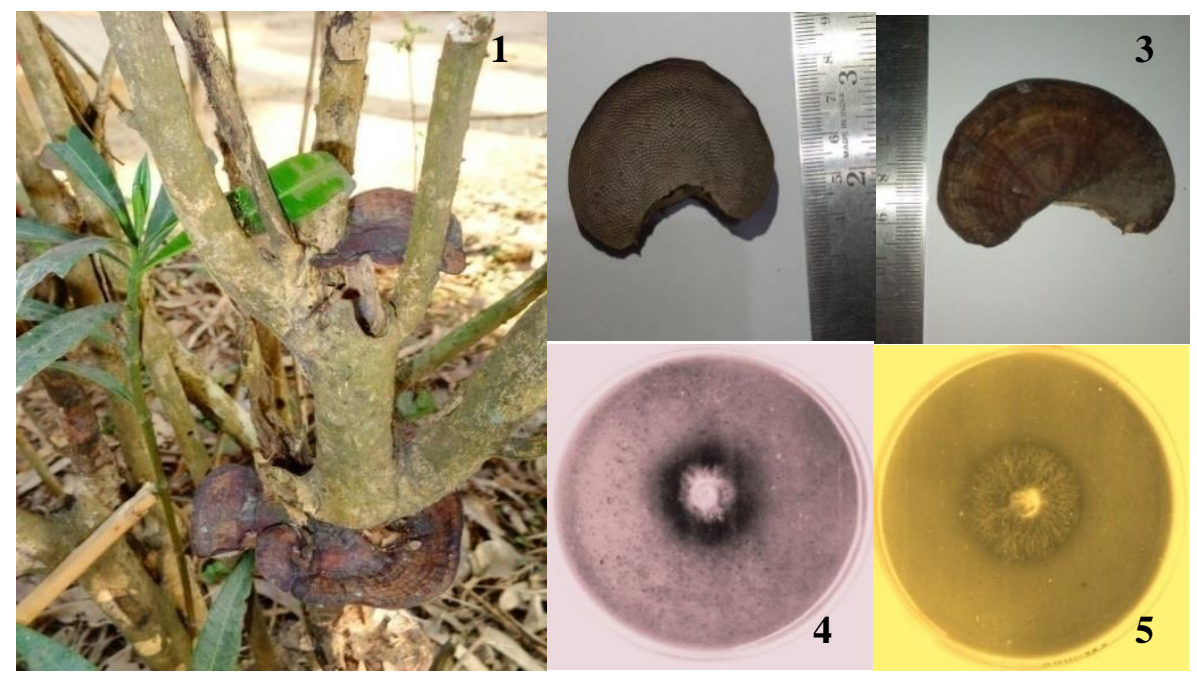

Figs 1-5 - Hexagonia tenuis 1, Basidiocarps on Nerium odorum. 2, Lower surface of basidiocarp. 3, Upper surface of basidiocarp. 4, Oxidase positive on gallic acid agar. 5, Oxidase positive on tannic acid agar.

\section{Discussion}

Hexagonia tenuis causes white rot of its host (Roy \& De 1979, Leite 1994). Production of a dark zone around the colony in the oxidase test shows that it is a white rot fungus, which confirms that the basidiocarps collected from Nerium odorum is H. tenuis. Hosts of Hexagonia tenuis are listed in Table 1.

The present study provides the first record of H. tenuis on Nerium odorum. Carissa sp. is the only other plant of Apocynaceae which has been recorded as a host for H. tenuis (Ranadive et al. 2013). 
Table 1 Hosts of Hexagonia tenuis along with respective references.

\begin{tabular}{|c|c|c|}
\hline Host & Family & Reference \\
\hline Mangifera indica $\mathrm{L}$. & Anacardiaceae & $\begin{array}{l}\text { Roy \& De } 1979 \\
\text { Pandit } 2016\end{array}$ \\
\hline Hevea brasiliensis (HB. \& K.) Muell-Arg. & Euphorbiaceae & Seephueak 2012 \\
\hline Dimocarpus longan Lour. & Sapindaceae & Anonymous 2015 \\
\hline Delonix regia Raf. & Leguminosae & \\
\hline Ficus microcarpa L. f. & Moraceae & \\
\hline Grevillea robusta A. Cunn. & Proteaceae & Spaulding 1961 \\
\hline Anacardium occidentale L. & Anacardiaceae & Leelavathy \& \\
\hline Calycopteris floribunda (Rox.) Poir. & Combretaceae & Ganesh 2000 \\
\hline Moringa oleifera Lam. & Moringaceae & \\
\hline Dysoxylum gaudichaudianum (A. Juss.) & Meliaceae & Tadiosa et al. 2011 \\
\hline Miq. & & \\
\hline Tectona grandis L. f. & Verbenaceae & $\begin{array}{l}\text { Tiwari \& Harsh } \\
2005\end{array}$ \\
\hline Pterocarpus angolensis DC. & Leguminosae & Mehl 2010 \\
\hline Caesalpinia spinosa (Mol.) Kuntze & Leguminosae & Arenas et al. 2015 \\
\hline Acacia catechu Willd. & Leguminosae & Bakshi 1971 \\
\hline Albizzia stipulata Bovin & Leguminosae & \\
\hline Casuarina montana Leschin ex Miq. & Casuarinaceae & \\
\hline Eriobotrya japonica Lindt. & Rosaceae & \\
\hline Mallotus philippinensis Muell-Arg. & Euphorbiaceae & \\
\hline Psidium guyava $\mathrm{L}$ & Myrtaceae & \\
\hline Shorea robusta Gaertn. f. & Dipterocarpaceae & \\
\hline Carissa sp. & Apocynaceae & $\begin{array}{l}\text { Ranadive et al. } \\
2013\end{array}$ \\
\hline
\end{tabular}

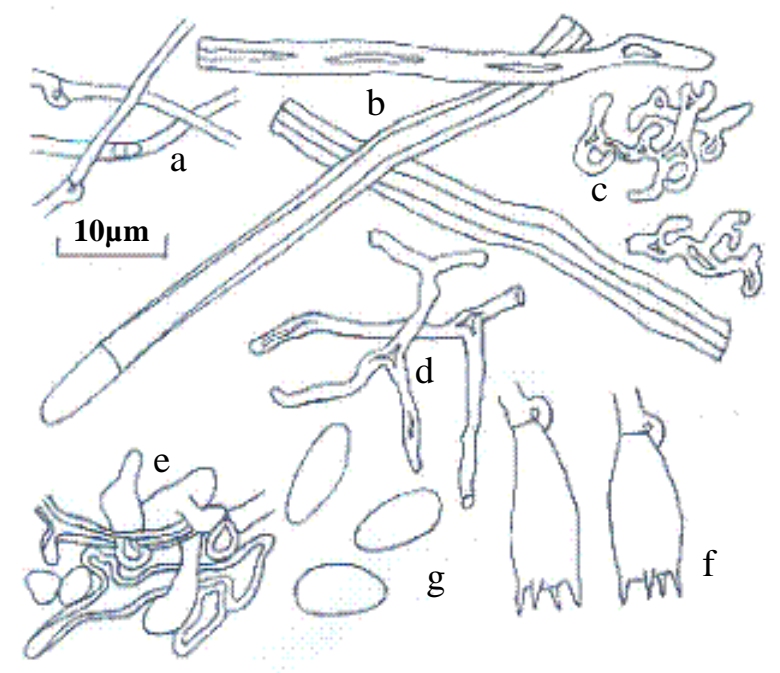

Fig. 6 - Microscopic characters of basidiocarps of Hexagonia tenuis. a, generative hyphae. b, skeletal hyphae. c, coralloid binding hyphae. d, binding hyphae with short free branches. e, cuticular cells along with thick-walled hyphae occurring in the crustose area. f, basidia. g, basidiospores. 
In the present study $H$. tenuis was found to produce basidiocarps on stems of Nerium odorum of diameter less than $3 \mathrm{~cm}$. However, H. tenuis has also been reported to grow on logs and branches of wider diameter of various trees such as Hevea brasiliensis (Seephueak 2012) and Dimocarpus longan (Anonymous 2015). Thus, the present observation supports the view of Adarsh et al. (2015) who suggested that some polypores growing on wood of small diameter can usually grow on large $\operatorname{logs}$ as well. Hattori \& Lee (2003) found that in Malaysia Coriolopsis retropicta, Microporus xanthopus and Trametes mimetes are mostly restricted to twigs or small trunks $(<10 \mathrm{~cm}$ in diameter), whereas Ganoderma australe, Phellinus lamaensis and Rigidoporus microporus occur on larger substrates. Similarly, in a study in an Andean alder wood in Argentina, Urcelay \& Robledo (2004) observed a preference for large diameter logs $(25-30 \mathrm{~cm})$ to support fruiting by Trametes cubensis and Phellinus gilvus while Bjerkandera adusta and Lenzites betulina were characterised by having the highest frequency on logs of intermediate diameter $(10-15 \mathrm{~cm})$. Datronia mollis, Hexagonia papyracea, Polyporus tricholoma formed a group that was always found on branches with small diameter $(<10 \mathrm{~cm})$.

\section{Acknowledgements}

The author is indebted to Dr S.K. Mukherjee and Dr P.K. Saha of Department of Microbiology, The University of Burdwan, West Bengal, India for providing laboratory facilities to conduct this work. The author is also grateful to $\mathrm{Mr}$ Anirban Samanta and $\mathrm{Mr}$ Amlan Mahata of Department of Microbiology, The University of Burdwan, for their generous help in doing this work.

\section{References}

Adarsh CK, Vikas K, Vidyasagaran K, Ganesh PN. 2015 - Decomposition of wood by polypore fungi in tropics-biological, ecological and environmental factors-a case study. Research Journal of Agriculture and Forestry Sciences 3(8), 15-37.

Anonymous. 2015 - Note on common wood decay fungi on urban trees of Hong Kong. Greening, Landscape and Tree Management Section Development Bureau, The Government of Hong Kong.

Arenas MC, Tadiosa ER, Alejandro GJD, Reyes RG. 2015 - Macroscopic fungal flora of Mts. Palapalay-Mataas na Gulod protected landscape, southern Luzon, Philippines. Asian Journal of Biodiversity 6, 1-22.

Bakshi BK. 1971 - Indian Polyporaceae (on trees and timber). ICAR, New Delhi, India.

Davidson RW, Campbell WA, Blaisdell DJ 1938 - Differentiation of wood-decaying fungi by their reaction on gallic or tannic acid medium. Journal of Agricultural Research 7, 683-695.

Hattori T, Lee SS. 2003 - Community structure of wood decaying Basidiomycetes in Pasoh. In: Okuda T, Manokaran N, Matsumoto Y, Niiyama K, Thomas SC (eds.) Pasoh: ecology of a lowland rain forest in South East Asia. Springer,Tokyo.

Leelavathy KM, Ganesh PN. 2000 - Polypores of Kerala. Daya Publishing House, Delhi, India.

Leite CL. 1994 - Polyporaceae on the Santa Catarina Island (South Brazil) I1I: the genus Hexagonia Fr. Insula, Florianópolis, $\mathrm{N}^{\circ} 23,3-14$.

May TW. 2017 - Biogeography of Australasian fungi: from mycogeography to the mycobiome. In: Ebach MC (ed.) Handbook of Australasian Biogeography. CRC Press, Taylor \& Francis, pp. 55-214.

Mehl JWM. 2010 - Fungi associated with the die-back of Pterocarpus angolensis (kiaat) in South Africa. Thesis, University of Pretoria, Pretoria, South Africa.

Pandit MV. 2016 - Preliminary investigations of Aphyllophorales from Saurashtra University Campus, Rajkot (Gujrat), India. International Journal of Science Info (IJSI), 1(3), 144-150.

Ranadive KR, Jite PK, Ranade VD, Vaidya JG. 2013 - Flora of Aphyllophorales from Pune District-Part I. Journal on New Biological Reports 2(3), 188-227. 
Roy A, De AB. 1979 - Interfertility studies on eight species of Polyporaceae. Mycologia 71(3), 655-658.

Seephueak P. 2012 - Fungi associated with degradation of rubber wood logs and leaf litter. Thesis, Prince of Songkla University, Thailand.

Spaulding P. 1961 - Foreign diseases of forest trees of the world; an annotated list. Agriculture Handbook No.197, U.S. Department of Agriculture.

Tadiosa ER, Agbayani ES, Agustin NT. 2011 - Preliminary study on the macrofungi of BazalBaubo Watershed, Aurora Province, Central Luzon, Philippines. Asian Journal of Biodiversity 2, 149-171.

Tiwari CK, Harsh NSK. 2005 - Wood decaying fungi of teak from Madhya Pradesh, India. Indian Forester 131(2), 215-220.

Urcelay C, Robledo G. 2004 - Community structure of polypores (Basidiomycota) in Andean alder wood in Argentina: functional groups among wood-decay fungi? Austral Ecology 29, 471476. 